\title{
Interactive effects of temperature and salinity on shell formation and general condition in Baltic Sea Mytilus edulis and Arctica islandica
}

\author{
C. Hiebenthal ${ }^{1, *}$, E. E. R. Philipp ${ }^{2}$, A. Eisenhauer ${ }^{3}$, M. Wahl ${ }^{1}$ \\ ${ }^{1}$ Helmholtz Centre for Ocean Research Kiel (GEOMAR), Benthic Ecology, Düsternbrooker Weg 20, 24105 Kiel, Germany \\ ${ }^{2}$ Institute of Clinical Molecular Biology, Schittenhelmstr. 12, $24105 \mathrm{Kiel}$, Germany \\ ${ }^{3}$ Helmholtz Centre for Ocean Research Kiel (GEOMAR), Marine Biogeochemistry, Wischhofstr. 1-3, 24148 Kiel, Germany
}

\begin{abstract}
Stress often induces metabolically expensive countermeasures. Bivalve shell production is costly and can thus be indirectly impacted by environmental stress. Suboptimal salinity and temperature may constitute stressors that allocate energy away from shell production to cellular processes such as osmoregulation or to the repair of cellular damage. In the course of climate change, water temperatures of the Baltic Sea are predicted to increase, and salinity is predicted to regionally decrease. These shifts may lead to increased stress for temperate marine species adapted to relatively cool water temperatures and high salinity conditions. To better understand the importance of climate change-related stress, we assessed the isolated and interactive effects of salinity and temperature on shell increment (cumulative growth: shell), cellular oxidative stress (accumulation of oxidized lipids and proteins: lipofuscin), instantaneous physiological condition (condition index: CI), and mortality of young Mytilus edulis and Arctica islandica from the western Baltic Sea. Temperature and salinity interactively affected shell increment, lipofuscin accumulation, and mortality of $M$. edulis as well as shell increment of $A$. islandica. Shell increment of $M$. edulis was less affected by hyposalinity than shell increment of $A$. islandica. In both species the CI decreased and lipofuscin accumulation increased with increasing temperature. Lipofuscin accumulation negatively correlated with shell increment in $M$. edulis. We conclude that Baltic Sea populations of ecologically relevant bivalve species may experience severe stress by the predicted regional scenario of warming and desalination if evolutionary adaptation does not happen at a similar rate.
\end{abstract}

KEY WORDS: Mytilus edulis · Arctica islandica $\cdot$ Growth $\cdot$ Condition $\cdot$ Cellular stress $\cdot$ Mortality

\section{INTRODUCTION}

Bivalve growth rates may be affected by food availability, competition for space, wave exposure, light, $\mathrm{pH}$, temperature, and salinity (Malone \& Dodd 1967, Seed 1976, Bayne \& Worrall 1980, Kautsky 1982, Wong \& Levinton 2004, Berge et al. 2006). Bivalve growth is costly and includes shell production, which involves calcification and the formation of the organic matrix (Palmer 1992, Irie \& Iwasa 2005). Stress was recently defined as 'the impact of any set of abiotic and/or biotic factors that adversely affects individual "performance" and ultimately impairs population growth rate through reduced individual survival, growth and/or reproduction' (Wahl et al. 2011, p. 39). If, under conditions of limited energy supply, resources allocated to stress response processes are no longer available for shell and soft tissue production, cumulative growth (including shell increment) and instantaneous general physiological condition (con- 
dition index: CI) of bivalves should be sensitive to physiological stress. Hyper- or hyposaline conditions may cause physiological stress as they force the animal to invest more energy into ion regulatory processes (Silva \& Wright 1994, Deaton 2001). Furthermore, physiologically stressful conditions (e.g. salinities and temperatures outside the individual's optimum) can increase cellular damage in marine invertebrates due to an increased generation of reactive oxygen species (ROS: $\mathrm{O}_{2}^{-}, \mathrm{H}_{2} \mathrm{O}_{2}, \mathrm{OH}^{-}$) (Abele et al. 2002, Abele \& Puntarulo 2004). Removal of the damaged cell structures by proteasomes and lysosomes requires energy, is often incomplete, and can result in waste accumulation (Terman 2001, Brunk \& Terman 2002b). The 'aging pigment' lipofuscin represents such damaged cell structures, mainly oxidised proteins and lipids, which were incompletely degraded. Largely indigestible, lipofuscin accumulates in the lysosomes (Terman 2001, Brunk \& Terman 2002b) and can be used as a biomarker for lifetime oxidative cell damage (Winston 1991, Brunk \& Terman 2002a, Philipp et al. 2006). In marine molluscs, increased lipofuscin accumulation has been measured under physiological stress caused by pollution (Krishnakumar et al. 1997, Kagley et al. 2003, Aarab et al. 2008) or high temperatures (Abele et al. 1998).

Mytilus edulis is a eurythermal bivalve species that can survive transient high temperatures of $27^{\circ} \mathrm{C}$ ( $<10 \%$ mortality after $2 \mathrm{~d}$ ) as well as freezing (Read \& Cumming 1967, Williams 1970, Almada-Villela et al. 1982, Seed \& Suchanek 1992). The species' geographical range includes areas with salinities of 4 to 5 (e.g. in the Baltic Proper, leading to dwarfism) and areas where salinity may exceed 40 (e.g. in rock pools on the Atlantic coast [Newell 1979]). The optimum temperature for shell increment (cumulative growth: shell) of $M$. edulis has been reported to be $20^{\circ} \mathrm{C}$ (Almada-Villela et al. 1982, Reuter 2004). The optimum salinity for shell increment of this species is 24 (Almada-Villela 1984, Kossak 2006).

Arctica islandica reaches its eastern limit of distribution in the Baltic Sea at an average salinity of $\sim 10$ (von Oertzen \& Schulz 1973, Darr et al. 2008). Young A. islandica from the Atlantic Ocean (salinity 35) tolerate hyposalinity of 15 for more than $27 \mathrm{~d}$ (Kraus et al. 1991) and temperatures ranging from 1 to $20^{\circ} \mathrm{C}$ (Merrill et al. 1969, Cargnelli et al. 1999). The optimal temperature for shell increment of $A$. islandica is $12^{\circ} \mathrm{C}$ (Witbaard et al. 1997). So far, no controlled salinity experiments have been conducted with $A$. islandica. While final maximum shell sizes of this species are higher in the fully marine North Atlantic than in the brackish Kiel Bight, shell increment rates reported for young Baltic A. islandica (Brey et al. 1990) are similar or higher than those reported for North Atlantic populations (Schöne et al. 2005, Begum et al. 2010, Ridgway et al. 2011).

Given the projected changes in temperature and salinity in the course of climate change and the gaps in knowledge about their single and combined effects on important Baltic bivalve species, we investigated the influence of both environmental factors on lipofuscin accumulation, CI, mortality, and shell increment in 2 bivalve populations from the western Baltic Sea. The investigated bivalve species, Arctica islandica and Mytilus edulis, live in the North Atlantic as well as in the Baltic Sea (Loosanoff 1953, Theede et al. 1969, Gosling 1992, Bers 2006). While A. islandica burrows into the sandy sea bottom, M. edulis is attached to hard substrata (Seed \& Suchanek 1992, Witbaard \& Bergman 2003) or forms loose beds on sandy bottoms. In the Baltic Sea, M. edulis often dominates communities of shallow hard-bottom habitats (e.g. Jansson \& Kautsky 1977, Reusch \& Chapman 1997), and A. islandica frequently is dominant in western Baltic soft-bottom habitats below the halocline $(\sim 15 \mathrm{~m})$ (Brey et al. 1990, Zettler et al. 2001). The Baltic Sea populations of both species are spread out over an area with a pronounced large-scale salinity gradient and they experience strong local temporal fluctuations of both salinity and temperature (see 'Materials and methods' for typical ranges of temperature and salinity in Kiel Bight). Both bivalve species play important roles as biomass producers (Brey et al. 1990, Reusch \& Chapman 1997), enhancers of bentho-pelagic coupling (Kautsky 1981, Brey et al. 1990), reducers of water turbidity (Kautsky \& Evans 1987, Lozan et al. 1996), and ecosystem engineers (Lohse 1993, Borthagaray \& Carranza 2007, Norling \& Kautsky 2007). Environmental changes that affect survival or competitiveness of $M$. edulis or $A$. islandica can substantially alter regional ecosystem services.

The combination of stressors can cause antagonistic, synergistic, and additive effects (Wahl et al. 2011), making predictions from single-stress studies to climate change effects difficult. Therefore, a 2factorial experimental design was chosen to assess isolated and interactive effects of the 2 putative stressors in various combinations on a series of response variables in the 2 bivalve populations. Both the regional habitat that Mytilus edulis was collected from and the distributional range of this species include a wider array of the 2 abiotic variables inves- 
tigated here than the habitat and distributional range of Arctica islandica. Consequently, we hypothesized that $M$. edulis exhibits a broader stress tolerance than A. islandica, and we tested the bivalves' salinity tolerance over a range of temperatures that naturally occur in the habitats of both species $(4,10,16,20$, and $25^{\circ} \mathrm{C}$ for $M$. edulis, and 4,10 , and $16^{\circ} \mathrm{C}$ for $A$. islandica).

\section{MATERIALS AND METHODS}

The Baltic Sea is characterized by a marked salinity gradient, with salinities decreasing from $\sim 25$ in the Kattegat region to $\sim 16$ in the Kiel Bight to $<3$ in the northeastern Gulfs of Bothnia and Finland (Hansson \& Gustafsson 2011). Baltic Sea salinity strongly fluctuates around regional means as a consequence of water inflow from the North Sea, precipitation events, or upwelling (Hansson \& Gustafsson 2011). Salinity in Kiel Bight may vary between $\sim 10$ and $\sim 27$ (continuous logging of the German Federal Maritime and Hydrographic Agency [BSH] between 2004 and 2006). While the central and northern areas of the Baltic Sea are dominated by continental climate conditions with cold winters, warm summers, and moderate precipitation, milder and moister marine westcoast climate prevails in most of the southwestern and southern areas (HELCOM 2007).

Young Mytilus edulis specimens were collected in the Kiel Fjord (southwestern Kiel Bight) where salinity is on average $16.3( \pm 2.4 \mathrm{SD}$; min: 10.6, max: 23.8) and surface water temperatures range from $0.15^{\circ} \mathrm{C}$ in winter to $23.4^{\circ} \mathrm{C}$ (mean $10.48 \pm 6.13 \mathrm{SD}$ ) in summer (continuous logging of salinity and temperature by BSH between 2004 and 2006). The previous year's cohort of $M$. edulis was used in this experiment. Individual shell height (measured from the umbo [dorsal] to the opposite side of the shell [ventral]) of $M$. edulis ranged from 13.3 to $26.5 \mathrm{~mm}$ (mean $19.0 \pm 2.23 \mathrm{SD}$ ).

Arctica islandica specimens were dredged at $24 \mathrm{~m}$ depth at the station Süderfahrt $\left(54^{\circ} 32.6^{\prime} \mathrm{N}, 10^{\circ} 42.1^{\prime} \mathrm{E}\right)$ in central Kiel Bight. Here, salinity is on average 21.8 $( \pm 2.4 \mathrm{SD}$; $\min :$ 13.6, max: 27.1) and temperatures vary between 0.6 and $17.5^{\circ} \mathrm{C}$ (mean: $9.03 \pm 4.23 \mathrm{SD}$; continuous logging of salinity and temperature by the BSH between 2004 and 2006). The height (dorsoventral axis, see paragraph above) of A. islandica individuals ranged from 12.1 to $33.0 \mathrm{~mm}$ (mean $20.4 \pm 2.23 \mathrm{SD}$ ), which corresponds to an age of approximately 1.5 to $5 \mathrm{yr}$ in the western part of the Baltic Sea (Brey et al. 1990). A. islandica is the longest lived non-colonial animal, with maximum life spans > 400 yr (Wanamaker et al. 2008). Since Baltic Sea $A$. islandica can reach an age of at least $40 \mathrm{yr}$ (Begum et al. 2010), we considered all sampled specimens as 'young' individuals.

Bivalve populations of the western Baltic experience narrower ranges of environmental parameters than are observable over the entire distributional range of the species, and they differ in some phenotypic features from north Atlantic populations. The shells of Mytilus edulis from the Baltic Sea decrease in size (age-corrected) and thickness along the salinity gradient from the North Sea to the Bothnian Bay (Kautsky et al. 1990), while Arctica islandica is shorter-lived in the Baltic Sea $(\sim 40 \mathrm{yr})$ than in the north Atlantic (>200 yr) (Begum et al. 2010).

\section{Experimental design}

In order to explore possible interactions between treatment factors, we conducted a 2-factorial, fully crossed experiment for each species separately with the factors temperature and salinity. Treatment levels were $4,10,16,20$, and $25^{\circ} \mathrm{C}$ for Mytilus edulis and 4 , 10 , and $16^{\circ} \mathrm{C}$ for Arctica islandica regarding temperature, and 15, 25, and 35 regarding salinity for both species. These treatment levels fall within the natural range of temperature and salinity in the distributional range of the 2 species, while the sampled populations of both species only rarely, if ever, experience salinities $>25$ and temperatures $>23^{\circ} \mathrm{C}$. Each treatment combination of temperature and salinity was replicated 4 -fold, which required 60 (5 temperatures $\times 3$ salinities $\times 4$ replicates) $M$. edulis and 36 ( 3 temperatures $\times 3$ salinities $\times 4$ replicates) $A$. islandica independent experimental units.

\section{Culture}

Bivalves were kept in 96 temperature-insulated 41 containers at the Helmholtz Centre for Ocean Research Kiel (GEOMAR), with 10 ind. of Mytilus edulis, and 7 ind. of Arctica islandica in each container (experimental unit). Since individual bivalves of one experimental unit are interdependent pseudo-replicates, single uni-variate values (mortality of all individuals, mean shell increment, lipofuscin content and CI of single individuals) representing all individuals of one container where assigned to the replicates (experimental units). Bivalves were fed $0.5 \mathrm{ml}$ ind. ${ }^{-1} \mathrm{~d}^{-1}$ of a con- 
centrated living-phytoplankton suspension 5 times a week (DT's Premium Blend; DT's Plankton Farm) containing Nannochloropsis oculata (40\%), Phaeodactylum tricornutum (40\%), and Chlorella sp. (20\%). Algal biomass was approx. 2.91 g (dry weight) $\mathrm{l}^{-1}$, resulting in $1.5 \mathrm{mg}$ ind. ${ }^{-1} \mathrm{~d}^{-1}$. Oneeighth of the water volume per experimental unit (0.5 l) was exchanged twice a week. Temperature was recorded by loggers $\left(\mathrm{HOBO}{ }^{\circledR}\right.$ Onset Computer Corporation). Salinity was measured twice a week with a WTW conductometer (cond 330i; WTW). Both factors were kept constant for the experimental duration of 15 wk. Salinity levels were set by admixing freshly collected Baltic Sea water with either ion-exchanged water or artificial marine salt (SEEQUASAL). Individuals were allowed to slowly acclimatize to the respective treatments. Initial salinity corresponded to the salinity conditions in the habitat of provenance and was increased or decreased by 1 unit $\mathrm{d}^{-1}$. Initial temperature represented temperature conditions in the habitat of provenance, and it was subsequently changed by max. $1^{\circ} \mathrm{C} \mathrm{d}^{-1}$ until treatment conditions were reached. Dead bivalves were replaced by new specimens to keep the bivalve density constant. The newly introduced individuals were not considered for further analysis.

\section{Data collection}

Bivalves were marked individually with numbered discs (Ø: $2 \mathrm{~mm}$ ) glued to the shell after locally removing the periostracum to enhance adhesion. Shell height (dorso-ventral axis) was measured monthly after the acclimatisation phase to the nearest 0.02 $\mathrm{mm}$ using callipers. Mean shell increment rates of all bivalve individuals of one experimental unit were used as response variable for each replicate.

Best grown individuals of each experimental unit were chosen for measuring lipofuscin, because in the high temperature treatments $\left(20\right.$ and $\left.25^{\circ} \mathrm{C}\right)$ these were the only individuals providing enough soft tissue material for this measurement. After $15 \mathrm{wk}$ of incubation under different temperature and salinity regimes, the whole soft tissue of these individuals was removed from the shells and deep-frozen at $-80^{\circ} \mathrm{C}$. Individual frozen soft tissues were weighed. Shells were air-dried $\left(7 \mathrm{~d}\right.$ at $20^{\circ} \mathrm{C}$ ) and their dry weight recorded. The condition index was calculated as CI = soft tissue wet weight (frozen) $_{\text {/ }}$ shell dry weight. For comparison of different CI calculations see Davenport \& Chen (1987).
Lipofuscin contents were determined by an extraction method following Vernet et al. (1988) and Sukhotin et al. (2002). Frozen soft tissue material of whole animals was ground in liquid nitrogen and homogenised $(1: 20 \mathrm{w} / \mathrm{v})$ in a chloroform-methanol solution $(2: 1 \mathrm{v} / \mathrm{v})$. The homogenate was mixed with $100 \mathrm{mM} \mathrm{MgCl}_{2}$ solution (1 ml per each $4 \mathrm{ml}$ of chloroform-methanol). After $15 \mathrm{~min}$ of centrifugation at $2000 \times g$ and $0^{\circ} \mathrm{C}$, the chloroform phase was collected and washed with distilled water $(1 \mathrm{ml}$ per $4 \mathrm{ml}$ initial chloroform-methanol). Chloroform-water was centrifuged as above and the chloroform phase collected again and measured in a fluorometer. An emission spectrum was obtained at an excitation wavelength of $350 \mathrm{~nm}$. Fluorescence intensity of each sample was then determined at the emission maximum of $480 \mathrm{~nm}$. Following Hill \& Womersley (1993), lipofuscin contents were expressed as relative fluorescent intensity (RFI) using $0.1 \mu \mathrm{g}$ quinine sulphate per ml of $1 \mathrm{~N}$ $\mathrm{H}_{2} \mathrm{SO}_{4}$ as standard. As lipofuscin accumulates in the whole soft tissue over time (i.e. with age; Sukhotin et al. 2002, Philipp et al. 2005), and for reasons of better internal and external comparability, RFI values were corrected by the incubation time and height of the individual bivalves (as a proxy for age) at the experimental start: $\mathrm{RFI}_{\text {corr }}=\mathrm{RFI}$ (incubation time $\times$ start shell height) ${ }^{-1}$. True age was not determined but in young Mytilus edulis and Arctica islandica individuals age and size correlate well (e.g. Bayne \& Worrall 1980, Kautsky 1982, Begum et al. 2010). Mortality was expressed as percentage of mussels that died in an experimental unit during the experimental phase.

\section{Data analysis}

Data representing percentage values, namely mortality values, were arcsine-transformed. Not normally distributed data or those of unequal variances were (square root-, 4th- root, or log-) transformed to meet the necessary assumptions for an ANOVA. For one data set no transformation was successful (Mytilus edulis: CI). Here, the significance level $\alpha$ was lowered from 0.05 to 0.01 to reduce the risk of type- 1 errors (Glasby 1998). Data were analysed for significant differences between treatment levels by 2-factorial ANOVA. In the absence of interactive effects, differences between single treatment levels were identified by 1 -factorial Tukey's HSD post hoc test. Correlations between the response variables shell increment, lipofuscin accumulation, CI and mortality were determined with Pearson's correlation test. All statistical tests were run using the Statistica 8.0 software package. 


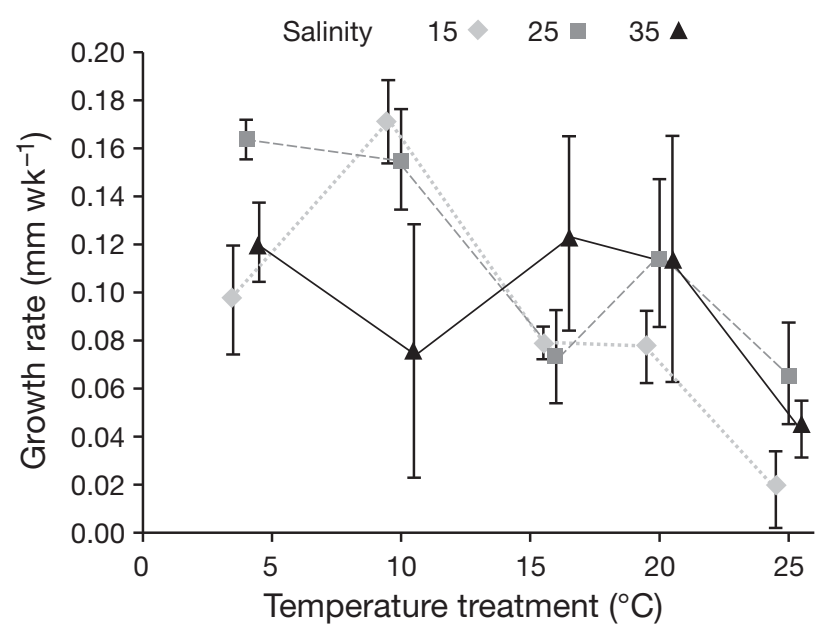

Fig. 1. Mytilus edulis. Shell increment rates $\left(\mathrm{mm} \mathrm{wk}^{-1}\right)$ of all individuals in the experimental units at different temperatures. Data: mean $\pm 95 \%$ confidence intervals; $\mathrm{n}=4$

\section{RESULTS}

\section{Mytilus edulis}

Growth (shell increment). Temperature and salinity affected shell increment of Mytilus edulis (Fig. 1) interactively (2-way ANOVA, $F=6.08, \mathrm{p}<0.001$ ). Trends of these interactive effects were a reduction of shell increment with increasing temperatures (especially at $25^{\circ} \mathrm{C}$ ), and at low (15) and high (35) salinity.

Stress. Temperature and salinity affected lipofuscin accumulation ( $\mathrm{RFI}_{\text {corr }}$ ) in Mytilus edulis interactively (2-way ANOVA, $F=2.74, \mathrm{p}=0.015$; Fig. 2). $\mathrm{RFI}_{\text {corr }}$ increased strongly at temperatures $>16^{\circ} \mathrm{C}$. At salinity 35 the $\mathrm{RFI}_{\text {corr }}$ increased already at $10^{\circ} \mathrm{C}$ causing the interaction. Lipofuscin contents were negatively correlated to shell increment $(\mathrm{r}=-0.40, \mathrm{p}=0.001)$.

Fitness parameters. CI of Mytilus edulis was not significantly affected by salinity (2-way ANOVA, $F=2.61, \mathrm{p}=0.085)$ but decreased with increasing temperatures (2-way ANOVA, $F=27.4, p<0.001$; Fig. 3A). The CI was positively correlated to shell increment $(r=0.37, p=0.003)$ and negatively to lipofuscin accumulation $(\mathrm{r}=-0.58, \mathrm{p}<0.001)$.

Mortality of Mytilus edulis was interactively affected by temperature and salinity (2-way ANOVA, $F=3.09$, $\mathrm{p}=0.007$; Fig. 3B). Low mortality was observed at salinity 25 and high mortality at treatment combinations salinity $35 / 10^{\circ} \mathrm{C}$ and salinity $15 / 25^{\circ} \mathrm{C}$. Mortality in the experimental units was negatively correlated to the shell increment of living mussels in the units $(\mathrm{r}=$ $-0.44, \mathrm{p}<0.001)$ but was neither correlated to the CI $(\mathrm{r}=0.06, \mathrm{p}=0.64)$ nor to $\mathrm{RFI}_{\text {corr }}(\mathrm{r}=0.05, \mathrm{p}=0.69)$.

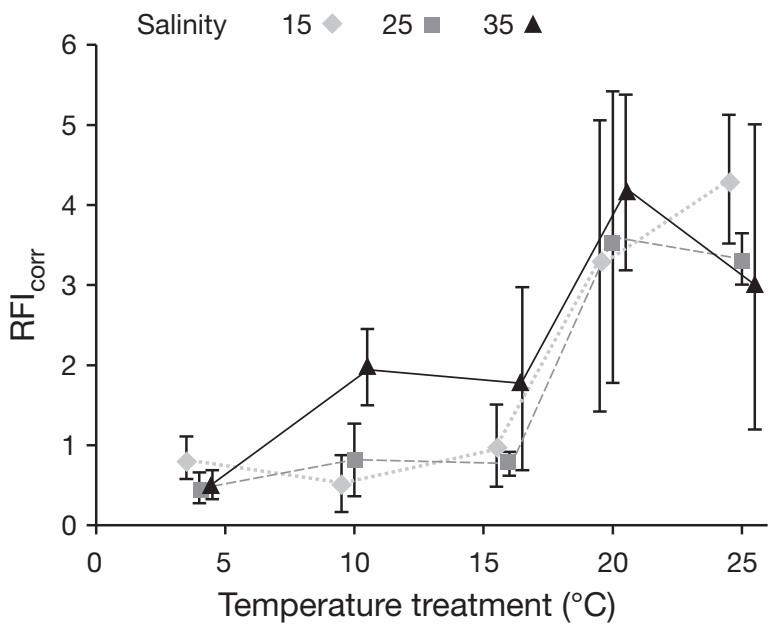

Fig. 2. Mytilus edulis. Relative fluorescence intensity $\left(\mathrm{RFI}_{\text {corr }}\right)$ of lipofuscin in measured individuals' soft tissue. Original values were corrected by incubation time and shell height at the start of the experiment. Data: mean $\pm 95 \%$ confidence intervals; $\mathrm{n}=4$

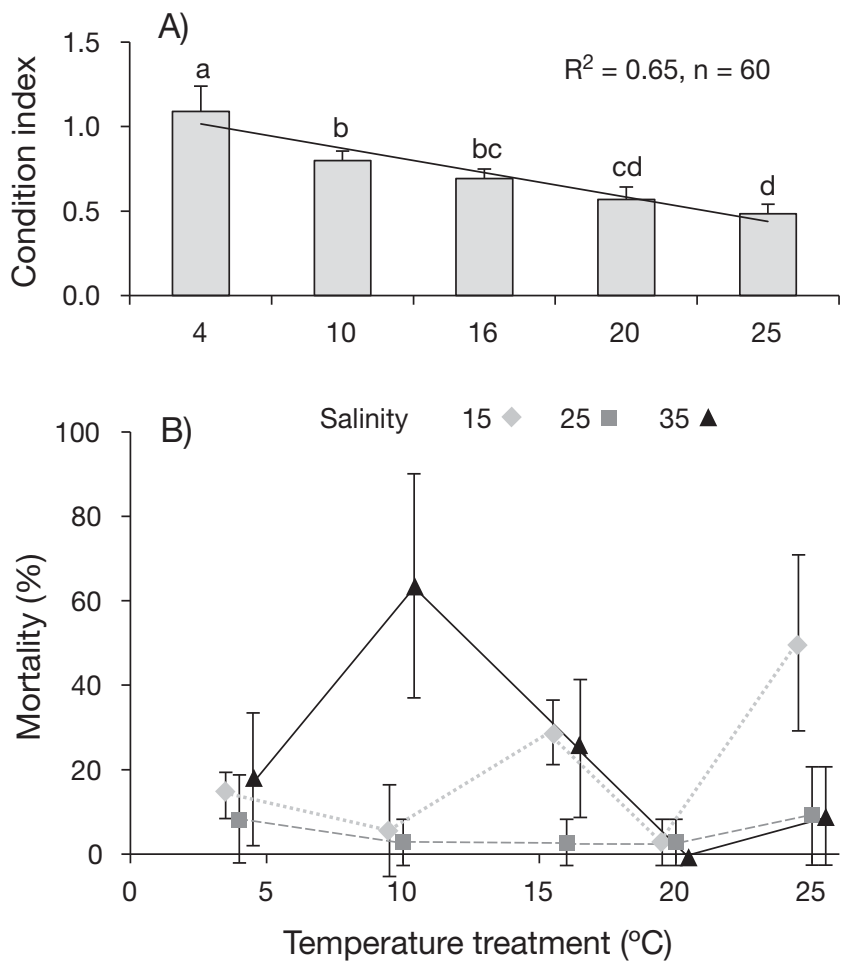

Fig. 3. Mytilus edulis. Fitness parameters. (A) Condition index (soft tissue weight / shell weight) of measured individuals and (B) interaction graph of mortality (\%) in the experimental units. Equal letters in (A) designate group comparisons for which statistically significant differences were not detected. Data: mean $\pm 95 \%$ confidence intervals; (A) $\mathrm{n}=12$; (B) $\mathrm{n}=4$ 


\section{Arctica islandica}

Growth (shell increment). Temperature and salinity affected shell increment of Arctica islandica interactively (2-way ANOVA, $F=3.12, \mathrm{p}=0.031$; Fig. 4 A) . While at $4^{\circ} \mathrm{C}$ the shell increment rate was highest at salinity 35 , the shell increment rate at 10 and $16^{\circ} \mathrm{C}$ was already high at salinity 25.
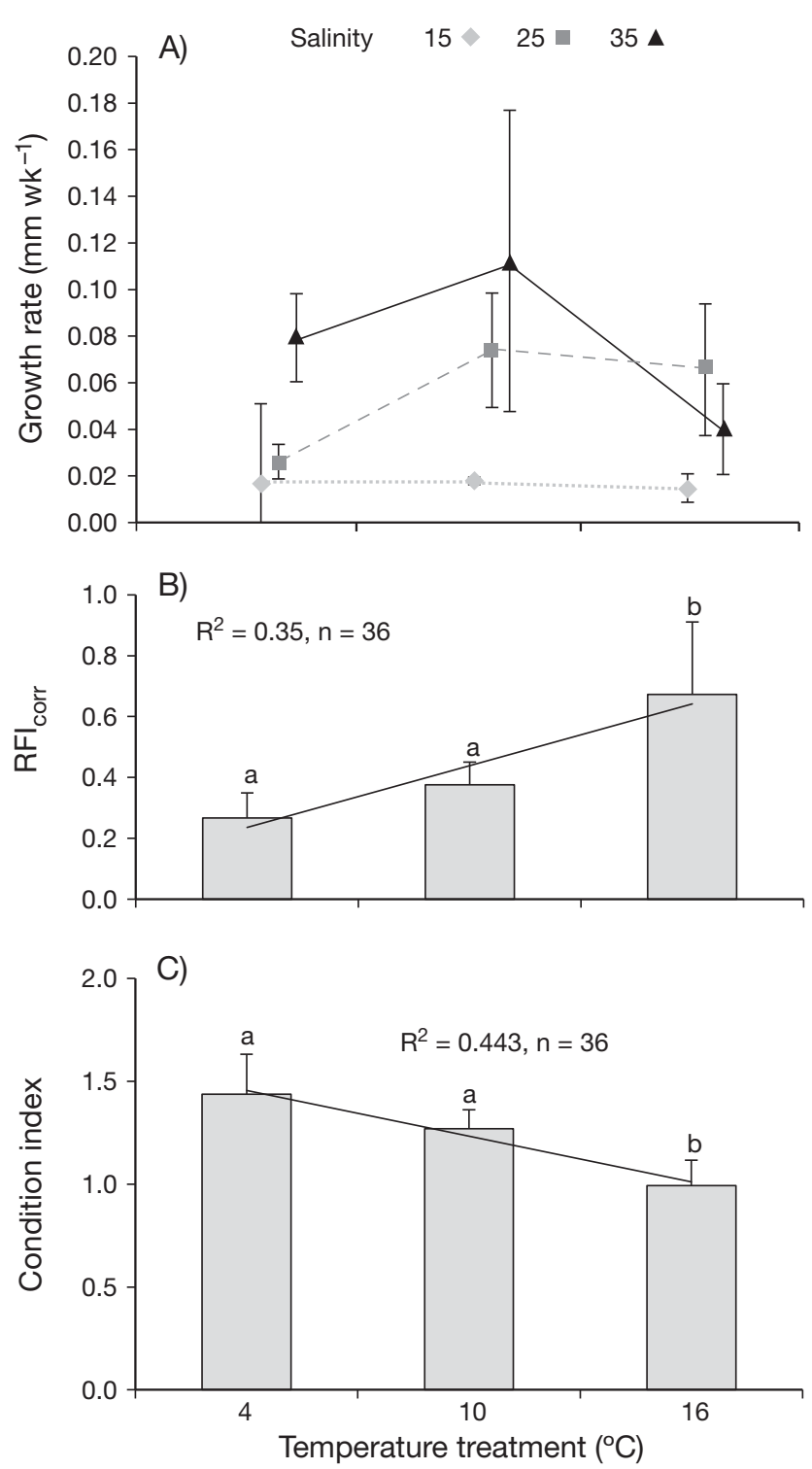

Fig. 4. Arctica islandica. (A) Mean shell increment rates (mm $\mathrm{wk}^{-1}$ ) of all individuals in the experimental units, (B) relative fluorescence intensity $\left(\mathrm{RFI}_{\text {corr }}\right)$ of lipofuscin in measured individuals' soft tissue (original values were corrected by incubation time and shell length at the start of the experiment), and $(\mathrm{C})$ condition index. In (B) and $(\mathrm{C})$ equal letters designate group comparisons for which statistically significant differences were not detected. Data: mean $\pm 95 \%$ confidence intervals. (A) $n=4$; (B) $n=12$; (C) $n=12$
Stress. When comparing lipofuscin content (RFIcorr) in the soft tissue of bivalves grown at temperatures 4 to $16^{\circ} \mathrm{C}$, the $\mathrm{RFI}_{\text {corr }}$ in Arctica islandica $(0.44 \pm 0.08 \mathrm{SE})$ was on average more than $50 \%$ lower than the $\mathrm{RFI}_{\text {corr }}$ in Mytilus edulis (mean RFIcorr of all measured $M$. edulis grown at temperatures 4 to $16^{\circ} \mathrm{C}: 0.97 \pm 0.20 \mathrm{SE}, t$-test: $t: 3.72, \mathrm{p}<$ 0.001). $\mathrm{RFI}_{\text {corr }}$ in $A$. islandica increased with temperature (2-way ANOVA, $F=14.5, \mathrm{p}<0.001$; Fig. 4B) but no statistically significant relation was detected between salinity and lipofuscin content in soft tissues of $A$. islandica (2-way ANOVA, $F=$ $0.08, p=0.92$ ). $\mathrm{RFI}_{\text {corr }}$ was not correlated to shell increment of A. islandica $(\mathrm{r}=-0.21, \mathrm{p}=0.30)$.

Fitness parameters. The CI of Arctica islandica was not influenced by salinity ( 2 -way ANOVA, $F=1.07, \mathrm{p}$ $=0.365$ ) but decreased with increasing temperature (2-way ANOVA, $F=10.32, \mathrm{p}=0.001$; Fig. $4 \mathrm{C}$ ). Additionally, the CI was negatively correlated to lipofuscin accumulation $(\mathrm{r}=-0.68, \mathrm{p}<0.001)$ but was not correlated to shell increment $(\mathrm{r}=0.03, \mathrm{p}=0.88)$.

Mortality of Arctica islandica was not influenced by temperature (2-way ANOVA, $F=0.15, \mathrm{p}=0.86$ ) but decreased with higher salinity (2-way ANOVA, $F=3.61, \mathrm{p}=0.04$; Fig. 5A,B). Mortality of A. islandica was not correlated to any of the other parameters (shell increment: $\mathrm{r}=-0.13, \mathrm{p}=0.45 \mathrm{RFI}_{\text {corr }}: \mathrm{r}=0.22$, $\mathrm{p}=0.27$; CI: $\mathrm{r}=0.18, \mathrm{p}=0.38$ ).

\section{DISCUSSION}

Temperature and salinity interactively affected shell increment rates, lipofuscin accumulation, and mortality of Mytilus edulis as well as shell increment rates of Arctica islandica. In both species, lipofuscin accumulation increased while the instantaneous general physiological condition (CI) decreased with increasing temperature. Lipofuscin accumulation of M. edulis was negatively correlated to the bivalve's shell increment rates.

The higher lipofuscin accumulation at higher temperatures in Mytilus edulis and Arctica islandica was expected since metabolic rates increase with increasing temperature in ectothermal organisms (e.g. Clarke 2003), which bears the risk of an elevation in free radical production leading to increased oxidative cellular damage (e.g. Abele 2002). The strong increase in lipofuscin accumulation further indicates that at higher temperatures the free radical defence and cellular repair mechanisms were not sufficient to prevent or reverse cellular damage (Terman \& Brunk 2004, Philipp et al. 2006). 

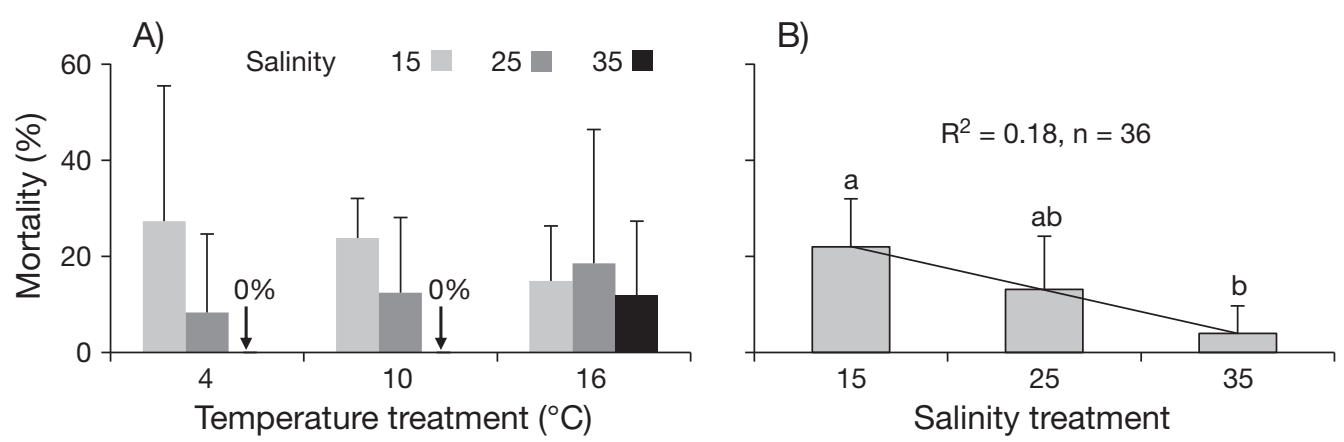

Fig. 5. Arctica islandica. Mortality (\%) in experimental units in (A) dependence on salinity and temperature and (B) pooled over all temperatures in dependence on salinity. In (B) equal letters designate group comparisons for which statistically significant differences were not detected. Data: mean $\pm 95 \%$ confidence intervals; $(A) n=4 ;(B) n=12$

The inverse relationship between the CI and lipofuscin accumulation appears to be due to positive feedbacks of both effects: reduced growth of soft tissue reduces the dilution of lipofuscin by cell proliferation (Sukhotin et al. 2002, Philipp et al. 2005). Furthermore, increasing lipofuscin contents reduce the functionality of body cells. Therefore, negative correlations of lipofuscin accumulation with shell increment rates and the CI corroborate the assumption that temperature stress may force Mytilus edulis to invest additional energy into cellular homeostasis, energy that then is lacking for animal's maintenance and shell production. For Arctica islandica, energy partitioning between cellular homeostasis and basal maintenance or growth only incompletely explains the results since shell increment and lipofuscin accumulation are affected by different abiotic factors (salinity and temperature, respectively). As lipofuscin content and the CI were influenced only by temperature and, as in $M$. edulis, inversely related to each other, the bivalves indeed suffered at higher temperatures. Yet, they suffered not so severely that shell increment of $A$. islandica was reduced.

Generally, a species' geographical distribution is not defined by single extrinsic factors that cause physiological stress. The reason is that any environmental factor can be modulated by biotic interactions as well as its interactions with other abiotic factors (e.g. $\mathrm{CO}_{2}$ ), which may cause unexpected effects (Wahl 2008, Wahl et al. 2011). The general increase of lipofuscin accumulation in Mytilus edulis with increasing temperature is more pronounced at salinity 35 as compared to the lower salinity treatments. Any departure from optimal salinity conditions (24 in M. edulis; Kossak 2006) requires osmoregulation (regulation of intracellular ion concentrations and organic osmolytes, especially free amino acids; Silva \& Wright 1994, Deaton 2001, Kube et al. 2006). This can require energy allocation away from antioxidant defence and cellular repair mechanisms, and may cause a further increase in metabolic rate, both mechanisms increasing lipofuscin accumulation (Resgalla et al. 2007). The up-regulation of intracellular organic osmolytes in response to increasing salinity can consist of breaking down of endogenous proteins, dietary assimilation, de novo synthesis, or uptake from the external media (Hawkins \& Hilbish 1992, Deaton 2001). Osmoregulation in response to an increase of salinity from 25 to 35 may therefore be energetically more expensive and may cause higher metabolic rates than down-regulation (decomposition, excretion, leaking-out) of osmolytes with decreasing salinity from 25 to 15 (Silva \& Wright 1994). This could explain why the threshold at which free radical production exceeds cellular defence and repair capacity (causing increased lipofuscin accumulation) is reached at lower temperatures at salinity 35 compared to salinities 25 (species' optimum) and 15 (habitat condition).

Shell increment and mortality of Mytilus edulis were impacted by non-optimal salinity conditions at 4, 10 , and $25^{\circ} \mathrm{C}$. In contrast, at 15 and $20^{\circ} \mathrm{C}$ there were no, or only small, salinity effects, suggesting that this temperature range may be most favourable for the mussels. Kossak (2006) showed that salinity and temperature effects on North and Baltic Sea M. edulis shell increment rates depend on nutrition levels. She found increasing shell increment with higher temperatures only at very high phytoplankton concentrations (double of typical present-day concentration in Kiel Bight). In field observations, Page \& Hubbard (1987) also observed that temperature and shell increment rates of $M$. edulis in California waters correlated due to an indirect nutrition effect via higher phytoplankton production at higher temperatures. In our experiment, we deliberately ex- 
cluded any nutrition effect by equal feeding at all treatment levels. Having now shown that the 2 environmental stressors directly and additively interact with each other, it is important to take salinity effects into account when considering effects of non-optimal temperatures on mussel performance and vice versa. Due to our non-ad-libitum nutrition routine, however, food limitation could have contributed to the reduction of shell increment of $M$. edulis at $25^{\circ} \mathrm{C}$.

Interacting effects of temperature and salinity on shell increment of Arctica islandica at $4^{\circ} \mathrm{C}$ in salinity 25 corroborate field observations of Begum et al. (2010), who found that the combination of reduced salinity (25) and low temperature $\left(4^{\circ} \mathrm{C}\right)$ is an especially harsh environment for A. islandica. Possibly, increased metabolic rates at temperatures 10 and $16^{\circ} \mathrm{C}$ observed in the present study compensated for shell increment decelerating effects of sub-optimal salinity (25). Such a positive temperature effect, however, may be too weak to compensate for reduced shell increment when salinity is reduced to 15 . At fully oceanic conditions (salinity 35), we found that shell increment increased from 5 to $10^{\circ} \mathrm{C}$, which is in accordance with findings from North Sea $A$. islandica (Witbaard et al. 1997). A further warming to $16^{\circ} \mathrm{C}$ led to reduced mean shell increment indicating thermal stress. Indeed, A. islandica's southern distribution in the North Sea coincides with the $16^{\circ} \mathrm{C}$ summer isotherm (Cargnelli et al. 1999, Witbaard \& Bergman 2003).

In summary, the responses of the 2 studied bivalve species to the applied stressors differ in several aspects. Performance (shell increment and the CI) of Mytilus edulis was mainly controlled by temperature and less by salinity. Future scenarios predict Baltic Sea temperatures to increase by 3 to $6^{\circ} \mathrm{C}$ and salinity to decrease regionally by up to 5 units with climate change (HELCOM 2007, Lehmann et al. 2011). This may cause additional physiological stress for the investigated bivalve populations of Kiel Bight, since both species already live below their salinity optimum year-round, and at or above their temperature optimum during summer. Unless $M$. edulis can adapt to the predicted conditions, our results imply that $M$. edulis may be less competitive due to increased cellular stress and food limitation if surface water temperatures in summer exceed $20^{\circ} \mathrm{C}$ more frequently but productivity and/or eutrophication does not increase. The expected desalination of the Baltic Sea would result in lower shell increment rates and higher mortality, especially of Arctica islandica. Warming will increase cellular damage, which would weaken the condition of A. islandica independently of, or in addition to, salinity stress. If the populations do not adapt fast enough, warming and desalination of the Baltic Sea may lead to a retreat of the 2 species, especially at their eastern boundary ranges, where salinity is most stressful. How severely organisms are impacted by warming and desalination will also depend substantially on the responses of interacting species and concurrent shifts in biotic interactions. These interactions must be investigated before sound predictions can be made about future distribution limits (Sareyka et al. 2011, Wahl et al. 2011).

Acknowledgements. We thank S. Hardenberg for conducting lipofuscin measurements, D. Abele for laboratory capacities, and M. Lenz for assistance with the statistical analysis. The authors also thank the anonymous reviewers for their valuable comments and suggestions that helped to improve the quality of this paper. This study was conducted within the framework of the European Scientific Foundation (ESF) project CASIOPEIA and funded by the German Research Foundation (Deutsche Forschungsgemeinschaft) DFG, project no. Ei272/20-1/-2.

\section{LITERATURE CITED}

Aarab N, Pampanin DM, Naevdal A, Oysaed KB, Gastaldi L, Bechmann RK (2008) Histopathology alterations and histochemistry measurements in mussel, Mytilus edulis collected offshore from an aluminium smelter industry (Norway). Mar Pollut Bull 57:569-574

Abele D (2002) The radical life-giver. Nature 420:27

Abele D, Puntarulo S (2004) Formation of reactive species and induction of antioxidant defence systems in polar and temperate marine invertebrates and fish. Comp Biochem Physiol A 138:405-415

Abele D, Burlando B, Viarengo A, Pörtner HO (1998) Exposure to elevated temperatures and hydrogen peroxide elicits oxidative stress and antioxidant response in the Antarctic intertidal limpet Nacella concinna. Comp Biochem Physiol B 120:425-435

Abele D, Heise K, Pörtner HO, Puntarulo S (2002) Temperature dependence of mitochondrial function and production of reactive oxygen species in the intertidal mud clam Mya arenaria. J Exp Biol 205:1831-1841

Almada-Villela PC (1984) The effects of reduced salinity on the shell growth of small Mytilus edulis. J Mar Biol Assoc UK 64:171-182

Almada-Villela PC, Davenport J, Gruffydd LD (1982) The effects of temperature on the shell growth of young Mytilus edulis L. J Exp Mar Biol Ecol 59:275-288

> Bayne BL, Worrall CM (1980) Growth and production of mussels Mytilus edulis from two populations. Mar Ecol Prog Ser 3:317-328

Begum S, Basova L, Heilmayer O, Philipp EER, Abele D, Brey T (2010) Growth and energy budget models of the bivalve Arctica islandica at six different sites in the northeast Atlantic realm. J Shellfish Res 29:107-115

Berge J, Johnsen G, Nilsen F, Gulliksen B, Slagstad D, Pampanin DM (2006) The Mytilus edulis population in Svalbard: how and why. Mar Ecol Prog Ser 309:305-306 
Bers AV (2006) Antifouling protection at different scales: multiple defence in Mytilus edulis and the global performance of mytilid microtopographies. $\mathrm{PhD}$ dissertation, Kiel University

> Borthagaray AI, Carranza A (2007) Mussels as ecosystem engineers: their contribution to species richness in a rocky littoral community. Acta Oecol Int J Ecol 31: 243-250

> Brey T, Arntz WE, Pauly D, Rumohr H (1990) Arctica (cyprina) islandica in Kiel Bay (western Baltic): growth, production and ecological significance. J Exp Mar Biol Ecol 136:217-235

> Brunk UT, Terman A (2002a) Lipofuscin: mechanisms of age-related accumulation and influence on cell function. Free Radic Biol Med 33:611-619

Brunk UT, Terman A (2002b) The mitochondrial-lysosomal axis theory of aging: accumulation of damaged mitochondria as a result of imperfect autophagocytosis. Eur J Biochem 269:1996-2002

Cargnelli L, Griesbach S, Packer D, Weissberger E (1999) Ocean quahog, Arctica islandica, life history and habitat characteristics. NOAA Tech Memo NMFS-NE-148, Woods Hole, MA

Clarke A (2003) Costs and consequences of evolutionary temperature adaptation. Trends Ecol Evol 18:573-581

Darr A, Meißner K, Sordyl H, Gusky M and others (2008) GIS-gestützter autökologischer Atlas benthischer wirbelloser Tiere in der deutschen Nord- und Ostsee. Version 11. CD-ROM, FKZ 0329997. Institut für Angewandte Ökologie und Alfred Wegener Institut, Neu Broderstorf

> Davenport J, Chen X (1987) A comparison of methods for the assessment of condition in the mussel (Mytilus edulis L.). J Moll Stud 53:293-297

Deaton LE (2001) Hyperosmotic volume regulation in the gills of the ribbed mussel, Geukensia demissa: rapid accumulation of betaine and alanine. J Exp Mar Biol Ecol 260:185-197

Glasby TM (1998) Estimating spatial variability in developing assemblages of epibiota on subtidal hard substrata. Mar Freshw Res 49:429-437

Gosling E (1992) Systematics and geographic distribution of Mytilus. In: Gosling E (ed) The mussel Mytilus: ecology, physiology, genetics and culture, Vol 25. Elsevier Science Publishers, Amsterdam

- Hansson D, Gustafsson E (2011) Salinity and hypoxia in the Baltic Sea since AD 1500. J Geophys Res Oceans 116: C03027, doi:10.1029/2010JC006676

Hawkins AJS, Hilbish TJ (1992) The costs of cell-volume regulation: protein-metabolism during hyperosmotic adjustment. J Mar Biol Assoc UK 72:569-578

HELCOM (2007) Climate change in the Baltic Sea area. Baltic Sea Environ Proc 111. Helsinki Commission

> Hill KT, Womersley CZ (1993) Interactive effects of some environmental and physiological variables on fluorescent age pigment accumulation in brain and heart tissues of an aquatic poikilotherm. Environ Biol Fishes 37: 397-405

Irie T, Iwasa Y (2005) Optimal growth pattern of defensive organs: the diversity of shell growth among mollusks. Am Nat 165:727

Jansson AM, Kautsky N (1977) Quantitative survey of hard bottom communities in a Baltic archipelago. In: Keegan BF, O'Ceidigh P, Boaden PJS (eds) Biology of benthic organisms. Proc 11th Europ Symp Mar Biol, Galway, Oct 1976. Pergamon Press, Oxford, p 359-366
Kagley AN, Snider RG, Krishnakumar PK, Casillas E (2003) Assessment of seasonal variability of cytochemical responses to contaminant exposure in the blue mussel Mytilus edulis (complex). Arch Environ Contam Toxicol 44:43-52

Kautsky N (1981) On the trophic role of the blue mussel (Mytilus edulis L.) in a Baltic coastal ecosystem and the fate of the organic matter produced by the mussels. Kiel Meeresforsch Sonderh 5:454-461

- Kautsky N (1982) Growth and size structure in a Baltic Mytilus edulis population. Mar Biol 68:117-133

> Kautsky N, Evans S (1987) Role of biodeposition by Mytilus edulis in the circulation of matter and nutrients in a Baltic coastal ecosystem. Mar Ecol Prog Ser 38:201-212

> Kautsky N, Johannesson K, Tedengren M (1990) Genotypic and phenotypic differences between Baltic and North Sea populations of Mytilus edulis evaluated through reciprocal transplantations. I. Growth and morphology. Mar Ecol Prog Ser 59:203-210

Kossak U (2006) How climate change translates into ecological change: impacts of warming and desalination on prey properties and predator-prey interactions in the Baltic Sea. PhD dissertation, Kiel University

Kraus M, Beal B, McMartin L (1991) Salinity and temperature tolerance tests on ocean quahogs, Arctica islandica (L.). J Shellfish Res 10:297 (Abstract)

> Krishnakumar PK, Casillas E, Varanasi U (1997) Cytochemical responses in the digestive tissue of Mytilus edulis complex exposed to microencapsulated PAHs or PCBs. Comp Biochem Physiol C 118:11-18

Kube S, Gerber A, Jansen JM, Schiedek D (2006) Patterns of organic osmolytes in two marine bivalves, Macoma balthica, and Mytilus spp., along their European distribution. Mar Biol 149:1387-1396

Lehmann A, Getzlaff K, Harlass J (2011) Detailed assessment of climate variability in the Baltic Sea area for the period 1958 to 2009. Clim Res 46:185-196

> Lohse DP (1993) The importance of secondary substratum in a rocky intertidal community. J Exp Mar Biol Ecol 166: $1-17$

Loosanoff (1953) Reproductive cycle in Cyprina islandica. Biol Bull (Woods Hole) 104:146-155

Lozan J, Lampe R, Matthäus W, Rachor E, Rumohr H, von Westernhagen H (1996) Warnsignale aus der Ostsee. Parey, Berlin

> Malone P, Dodd J (1967) Temperature and salinity effects on calcification rate in Mytilus edulis and its paleoecological implications. Limnol Oceanogr 12:432-436

Merrill AS, Chamberlain JL, Ropes JW (1969) Ocean quahog fishery. In: Firth FE (ed) Encyclopedia of marine resources. Van Nostrand Reinhold, New York, p 125-129

Newell RC (1979) Biology of intertidal animals. Marine Ecological Surveys, Faversham

Norling P, Kautsky N (2007) Structural and functional effects of Mytilus edulis on diversity of associated species and ecosystem functioning. Mar Ecol Prog Ser 351:163-175

Page HM, Hubbard DM (1987) Temporal and spatial patterns of growth in mussels Mytilus edulis on an offshore platform: relationships to water temperature and food availability. J Exp Mar Biol Ecol 111:159-179

> Palmer AR (1992) Calcification in marine mollusks: how costly is it? Proc Natl Acad Sci USA 89:1379-1382

> Philipp E, Brey T, Pörtner HO, Abele D (2005) Chronological and physiological ageing in a polar and a temperate mud clam. Mech Ageing Dev 126:598-609 
Philipp E, Brey T, Heilmayer O, Abele D, Pörtner HO (2006) Physiological ageing in a temperate and a polar swimming scallop. Mar Ecol Prog Ser 307:187-198

Read KRH, Cumming KB (1967) Thermal tolerance of the bivalve mollusc Modiolus modiolus (L.), Mytilus edulis (L.) and Brachiodontes demissus (Dillwyn). Comp Biochem Physiol 22:149-155

Resgalla C Jr, Brasil ED, Salomao LC (2007) The effect of temperature and salinity on the physiological rates of the mussel Perna perna (Linnaeus 1758). Brazil Arch Biol Technol 50:543-556

Reusch TBH, Chapman ARO (1997) Persistence and space occupancy by subtidal blue mussel patches. Ecol Monogr 67:65-87

Reuter P (2004) Einfluss klimarelevanter Faktoren auf das Wachstum der Miesmuschel (Mytilus edulis). MS thesis, Kiel University

Ridgway ID, Richardson CA, Scourse JD, Butler PG, Reynolds DJ (2011) The population structure and biology of the ocean quahog, Arctica islandica, in Belfast Lough, Northern Ireland. J Mar Biol Assoc UK, doi:10.1017/ S0025315411000154

Sareyka J, Kraufvelin P, Lenz M, Lindström M, Tollrian R, Wahl M (2011) Differences in stress tolerance and brood size between a non-indigenous and an indigenous gammarid in the northern Baltic Sea. Mar Biol 158:2001-2008

Schöne BR, Houk SD, Castro ADF, Fiebig J and others (2005) Daily growth rates in shells of Arctica islandica: assessing sub-seasonal environmental controls on a long-lived bivalve mollusk. Palaios 20:78-92

Seed R (1976) Ecology. In: Bayne BL (ed) Marine mussels. Cambridge University Press, Cambridge, p 13-65

Seed R, Suchanek T (1992) Population and community ecology of Mytilus. In: Gosling E (ed) The mussel Mytilus: ecology, physiology, genetics and culture. Elsevier Science Publishers, Amsterdam, p 87-170

Silva AL, Wright SH (1994) Short-term cell volume regulation in Mytilus californianus gill. J Exp Biol 194:47-68

Sukhotin AA, Abele D, Pörtner HO (2002) Growth, metabolism and lipid peroxidation in Mytilus edulis: age and size effects. Mar Ecol Prog Ser 226:223-234

Terman A (2001) Garbage catastrophe theory of aging: imperfect removal of oxidative damage? Redox Rep 6:

Editorial responsibility: Peter Beninger, Nantes, France
$15-26$

Terman A, Brunk UT (2004) Lipofuscin. Int J Biochem Cell Biol 36:1400-1404

Theede H, Ponat A, Hiroki K, Schlieper C (1969) Studies on the resistance of marine bottom invertebrates to oxygendeficiency and hydrogen sulphide. Mar Biol 2:325-337

Vernet M, Hunter JR, Vetter RD (1988) Accumulation of age pigments (lipofuscin) in two cold-water fishes. Fish Bull 86:401-407

von Oertzen JA, Schulz S (1973) Beitrag zur geographischen Verbreitung und ökologischen Existenz von Bivalviern in der Ostsee. Beitr Meereskunde 32:75-88

Wahl M (2008) Ecological modulation of environmental stress: interactions between ultraviolet radiation, epibiotic snail embryos, plants and herbivores. J Anim Ecol 77:549-557

- Wahl M, Jormalainen V, Eriksson BK, Coyer JA and others (2011) Stress ecology in Fucus: abiotic, biotic and genetic interactions. Adv Mar Biol 59:37-105

Wanamaker AD Jr, Heinemeier J, Scourse JD, Richardson CA, Butler PG, Eiriksson J, Knudsen KL (2008) Very long-lived mollusks confirm 17th century AD tephrabased radiocarbon reservoir ages for north Icelandic shelf waters. Radiocarbon 50:399-412

> Williams RJ (1970) Freezing tolerance in Mytilus edulis. Comp Biochem Physiol 35:145-161

- Winston GW (1991) Oxidants and antioxidants in aquatic animals. Comp Biochem Physiol C 100:173-176

Witbaard R, Bergman MJN (2003) The distribution and population structure of the bivalve Arctica islandica L. in the North Sea: what possible factors are involved? J Sea Res 50:11-25

- Witbaard R, Franken R, Visser B (1997) Growth of juvenile Arctica islandica under experimental conditions. Helgol Meersunters 51:417-431

> Wong WH, Levinton JS (2004) Culture of the blue mussel Mytilus edulis (Linnaeus, 1758) fed both phytoplankton and zooplankton: a microcosm experiment. Aquacult Res 35:965-969

Zettler ML, Bönsch R, Gosselck F (2001) Distribution, abundance and some population characteristics of the ocean quahog, Arctica islandica (Linnaeus, 1767), in the Mecklenburg Bight (Baltic Sea). J Shellfish Res 20:161-169

Submitted: September 23, 2011; Accepted: December 20, 2011 Proofs received from author(s): February 14, 2012 